
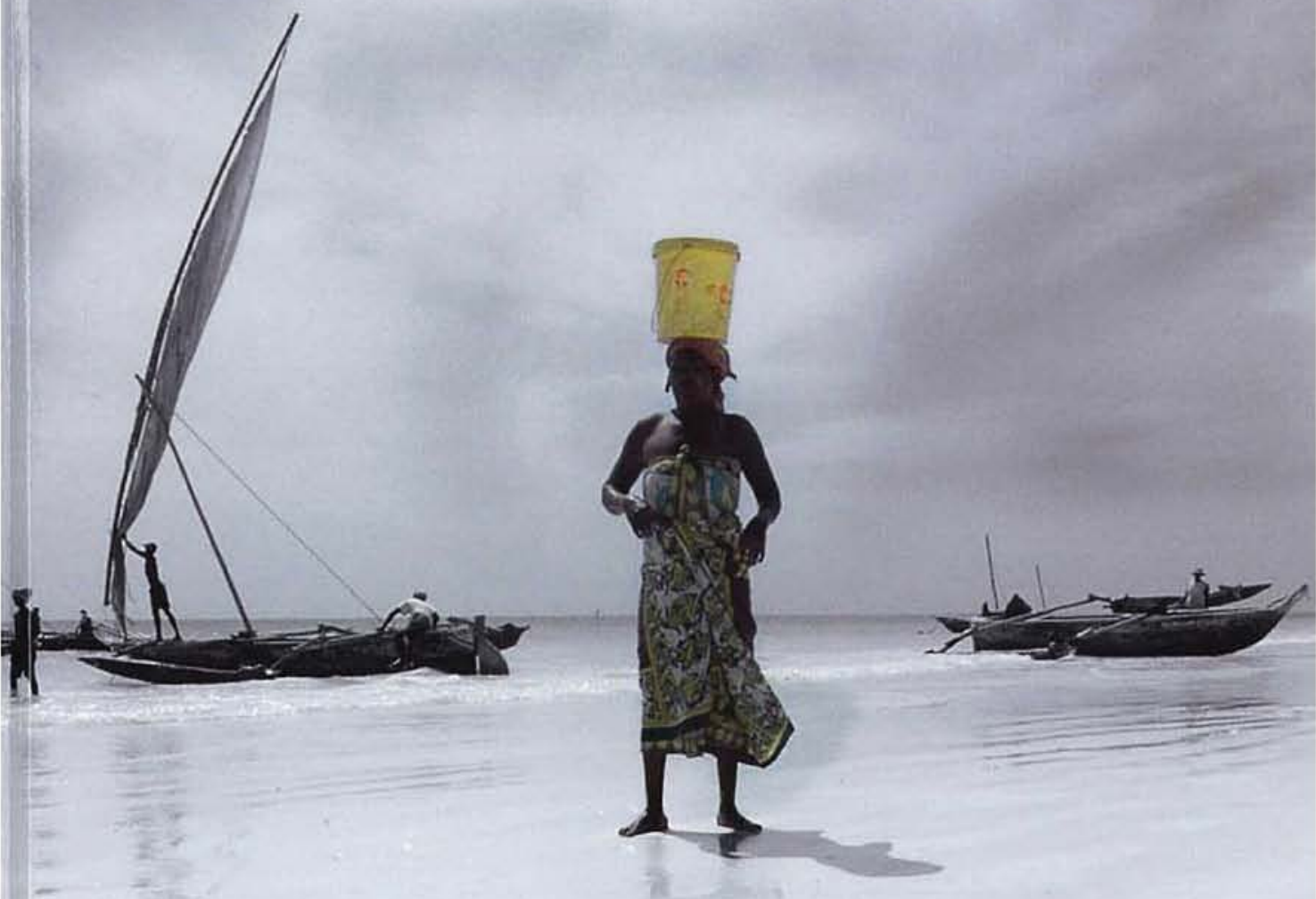

ADAPTING TO A CHANGING

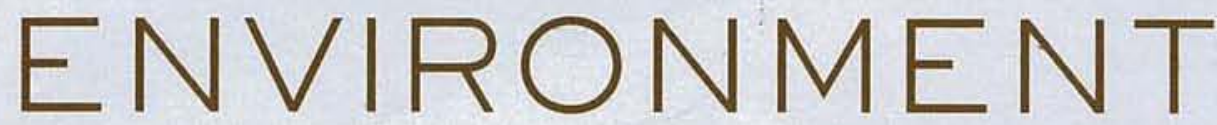

CONFRONTING THE CONSEQUENCES of Climate Change

TIM R. MCCLANAHAN and JOSHUA E. CINNER 


\section{Adapting to a Changing Environment}





\section{Adapting to a Changing Environment}

CONFRONTING THE CONSEQUENCES

OF CLIMATE CHANGE

Tim R. McClanahan

and

Joshua E. Cinner 


\section{OXFORD \\ UNIVBRSITY PRESS}

Oxford University Press, Inc., publishes works that further Oxford University's objective of excellence

in research, scholarship, and education.

Oxford New York

Auckland Cape Town Dar es Salaam Hong Kong Karachi

Kuala Lumpur Madrid Melbourne Mexico City Nairobi

New Delhi Shanghai Taipei Toronto

With offices in

Argentina Austria Brazil Chile Czech Republic France Greece

Guatemala Hungary Italy Japan Poland Portugal Singapore

South Korea Switzerland Thailand Turkey Ukraine Vietnam

Copyright @ 2012 by Oxford University Press, Inc.

Published by Oxford University Press, Inc,

198 Madison Avenue, New York, New York 10016

www.oup.com

Oxford is a registered trademark of Oxford University Press

All rights reserved. No part of this publication may be reproduced, stored in a retrieval system, or transmitted, in any form or by any means, electronic, mechanical, photocopying, recording, or otherwise, without the prior permission of Oxford University Press.

Library of Congress Cataloging-in-Publication Data

McClanahan, T. R.

Adapting to a changing environment : confronting the consequences of climate change / Tim R. McClanahan and Joshua E. Cinner.

p. cm.

Includes bibliographical references and index.

ISBN 978-0-19-975448-9 (hardcover : alk. paper)

1. Climatic changes. 2. Global environmental change. I. Cinner,

Joshua E., 1972- II. Title.

QC903.M395 2011

$304.2 ' 5-\mathrm{dc} 22$

2011007320

135798642

Printed in the United States of America

on acid-free paper 


\title{
CONTENTS
}

\author{
Preface vii \\ Acknowledgments ix \\ List of Abbreviations $\mathrm{xi}$
}

1. Climate Change, Resources, and Human Adaptation 1

2. The Global Context of Marine Fisheries 7

3. Climate Change and Oceanography 22

4. Climate Change and the Resilience of Coral Reefs 37

5. Climate Change and Coral Reef Fishes and Fisheries 57

6. Vulnerability of Coastal Communities 67

7. Coastal Communities' Responses to Disturbance 84

8. Linking Social, Ecological, and Environmental Systems 100

9. Building Adaptive Capacity 115

10. Managing Ecosystems for Change 134

11. Confronting the Consequences of Climate Change 150

Bibliography 154

Index 181 



\section{PREFACE}

The changing climate may fundamentally alter the land and sea as we know it. For those who depend on the beauty and bounty of the Earth's natural resources for their livelihoods-especially the world's poor-these changes could spell disaster. The problems climate change poses are complex, as are the ways in which societies cope with and adapt to change. Understanding and addressing these problems requires bridging diverse fields within the geophysical, ecological, and social sciences.

An ecologist and a social scientist, we have spent the last decade working together to integrate these fields. We approach the book from the perspective that social and ecological systems are intimately linked. Social processes, which can include cultural, political, and economic characteristics of society, influence the ways that people use and manage natural resources. Likewise, ecological conditions and processes can influence the societies' well-being.

Using this interdisciplinary approach, this book synthesizes, in simple terms, the rapidly emerging fields of climate change science and human adaptation and develops a practical framework for much-needed policy and adaptive responses. The framework addresses the differential responses of the environment, ecology, and people in affected areas, and identifies the policy action priorities based on this heterogeneity. We hope that this type of integrated analysis and problem solving will lead to policy actions that promote appropriate and lasting adaptations.

As a focal lens for these integrated climate change issues, we explore coral reefs and the coastal societies that depend on them throughout the eastern coastline of Africa and the islands of the western Indian Ocean. This is where many of the Earth's most impoverished people live. Here, both ecosystems and peoples' livelihoods are extremely sensitive to climate disturbances. Monsoonal rains, which are heavily influenced by climatic patterns, provide nearly all of the rainfall for the region's agriculture. Likewise, the islands and coasts are fringed by coral reefs, which provide livelihoods for millions of fishers and their dependants in the region, but are one of the most climatesensitive ecosystems. Considerable climate impacts have already occurred to the regions coral reefs-and even more severe ones are expected. This region, like others in poor tropical countries, has neither contributed much to rising greenhouse gas emissions, nor is it likely to contribute greatly to the efforts to mitigate climate change. Countries in the region will have little choice but 
to adapt, but these efforts will face considerable challenges from persistent poverty, implementing decisions, corruption, and other prevalent socioeconomic conditions.

The challenges of undertaking climate science, making the findings accessible, and catalyzing action are considerable, but this region is where these efforts and responses are most needed. Harsh realities will need to be confronted with decisions that increase the chances for successful adaptation. Although our book focuses on a specific geographic region and ecosystem, the conceptual framework we develop is applicable to most regions and climate change problems. Those interested in how climate change may influence other regions or systems can adapt the framework and approach we develop beyond the specific case we present. 


\section{ACKNOWLEDGMENTS}

We thank the Western Indian Ocean Marine Science Association (WIOMSA) through support from the Swedish International Development Corporation Agency (SIDA), and the John D. and Catherine T. MacArthur Foundation for their support of this book. WIOMSA's vision of interdisciplinary research toward practical problem solving has inspired much of our most satisfying research, and this book represents an effort to contextualize, synthesize, and build on these ideas. We also thank a large number of colleagues who have helped us during our research and preparation of this book, including helpful reviews and comments. These include Caroline Abunge, Eddie Allison, Mebrahtu Ateweberhan, Andrew Baird, Andrew C. Baker, Duan Biggs, Lionel Bigot, Tom Brewer, Katrina Brown, Henrich Bruggeman, Pascale Chabanet, Dee Cinner, Susan Clark, Tim Daw, David Feary, Chris Funk, Rene Galzin, Kajsa Garpe, Nick Graham, Mirielle Guilliame, Christina Hicks, Cindy Huchery, Simon Jennings, Albogast T. Kamukuru, Yves Letourneur, U. Lindhal, Joseph Maina, Nadine Marshall, Caleb McClennen, Nyawira Muthiga, Mohammed Sulieman, Ruby Moothien Pillay, Chris Muhando, Marcus Ohman, Nick Polunin, Carlos Ruiz Sebastián, Charles Sheppard, Mark Spalding, Selina Stead, Rashid Sumaila, Saleh Yahya, Andrew Wamukoto, Shaun Wilson, and Jens Zinke. 



\title{
LIST OF ABBREVIATIONS
}

\author{
AHP Analytic Hierarchy Process \\ BMU beach management units \\ BP before the present \\ CV coefficient of variation \\ EEZ exclusive economic zone \\ ENSO El Niño southern oscillation \\ FAO Food and Agriculture Organization \\ GDP gross domestic product \\ GELOSE Gestion Locale Sécurisée \\ HDI human development index \\ IOD Indian Ocean dipole \\ IPCC Intergovernmental Panel on Climate Change \\ ITCZ inter-tropical convergence zone \\ LMMA Locally Managed Marine Areas network \\ MPA marine protected area \\ MMSY multi-species maximum sustainable yield \\ NGO nongovernmental organization \\ NOAA National Oceanographic and Atmospheric Administration \\ OECD Organization for Economic Co-operation and Development \\ PAR photosynthetically active radiation \\ PDO Pacific decadal oscillation \\ PPP purchasing power parity \\ SIDA Swedish International Development Corporation Agency \\ SST sea-surface temperature \\ UNCLOS United Nations Convention on the Law of the Sea \\ UV ultraviolet \\ WIO western Indian Ocean \\ WIOMSA Western Indian Ocean Marine Science Association \\ WWF World Wildlife Fund
}

